\title{
Kinerja Pejabat Pengelola Informasi dan Dokumentasi (PPID) Kabupaten Bungo dalam Pemenuhan Ketersediaan Informasi Publik
}

\author{
Mela Sari ${ }^{\mathrm{a}, 1, *}$, Rizky Mulyadi ${ }^{\mathrm{b}, 2}$ \\ 1,2,3 Sekolah Tinggi Ilmu Administrasi Setih Setio Muara Bungo, Jambi, Indonesia \\ 1, melazuhel@gmail.com*, ${ }^{2}$ rizmul14@gmail.com \\ *corresponding author
}

\section{ARTICLE INFO}

Article history

Received 2020-11-10

Revised 2020-12-22

Accepted 2020-12-30

Keywords

Performance,

Public Information, Services

\begin{abstract}
Access to services in accordance with the Public Information Disclosure Act directs all public bodies that utilize state/local budgets, must have Pejabat Pengelola Informasi dan Dokumentasi (PPID) whose duties and obligations provide information services to the public in order for the distribution of information so that aspects that prioritize services can occur properly. This study examines how the PPID performance of Bungo Regency Government in the fulfillment of public information availability.

This research uses a qualitative method with descriptive analysis. Data analysis techniques using the model of Miles and Huberman. Furthermore, this study uses a data validity experiment using the Triangulation Method, namely by comparing information or data in different ways to obtain the correctness of information.

The results showed that the performance of PPID Bungo Regency in the fulfillment of the availability of public information has not been maximally shown resulting in the service of unsatisfactory information received by the community. The cause is due to the lack of public information. The public does not always get the public information that is intended. Nevertheless, the development of public data/information has not been carried out. As the main provider of public information, the Regional Device Organization (OPD) as the Auxiliary PPID in Bungo Regency has not performed the function of depositing information to the main PPID by applicable rules.
\end{abstract}

\section{PENDAHULUAN}

Informasi menjadikan salah satu kebutuhan utama bagi setiap manusia, disamping daripada kebutuhan akan sandang, pangan serta papan. Informasi terjadi atas dasar komunikasi antar individu satu dan individu yang lainnya. Berkomunikasi merupakan keharusan bagi manusia, karena dengan komunikasi beberapa kebutuhan manusia akan terpenuhi, baik kebutuhan pokok maupun kebutuhan kepentingan informasi. Kebutuhan akan memperoleh informasi pada saat sekarang ini sangatlah penting, karena setiap individu manusia dituntut untuk selalu mengikuti perkembangan zaman yang kian hari informasi terbarukan bukan hanya dengan hitungan per-hari melainkan pada hitungan detik sekalipun, sebagai akibat dari perkembangan teknologi informasi yang sangat pesat.

Kebutuhan informasi untuk masyarakat saat ini sudah tidak bisa dicegah dan dibatasi karena sekarang Indonesia memang memasuki era keterbukaan informasi sebagai bentuk daripada prinsip negara demokrasi yang mengharuskan partisipasi masyarakat terhadap pembangunan negara, yang ditunjang dengan adanya Undang-Undang Nomor 14 tahun 2008 tentang Keterbukaan Informasi Publik (KIP). Menurut Dhoho (2010:1), Keterbukaan informasi publik merupakan sarana dalam mengoptimalkan pengawasan publik terhadap penyelanggaraan Negara dan Badan Publik lainnya. Tiga isu besar yang menjadikan pendorong lahirnya kesadaran atas kebutuhan informasi pada UndangUndang keterbukaan informasi adalah upaya dalam pemberantasan korupsi, penegakan hak asasi manusia, dan tata kelola pemerintahan yang baik (good governance).

Di dalam undang-undang tersebut, prinsip-prinsip pelaksanaan pemerintahan yang baik, (good governance) dan akuntabel menjadi kewajiban bagi segenap penyelenggara layanan publik di Tanah Air. Keterbukaan informasi publik menjadikan ciri penting suatu negara demokratis yang menjunjung 
tinggi kedaulatan rakyatnya untuk mewujudkan tata penyelenggaraan negara yang baik. Dalam konteks masyarakat yang lebih luas, konsep transparansi informasi ini belum dipahami dengan baik. Sehingga konsekuensi keberadaan Undang-Undang keterbukaan informasi ini kurang populer dan implementasinya jauh dari harapan. Padahal banyak pihak berharap hadirnya regulasi ini mampu mendorong iklim keterbukaan yang luas diberbagai badan publik.

Mardiasmo (2014:31) berpendapat bahwa Pemerintah sebagai pelayan masyarakat harus dapat menjadi pemberi informasi yang mahir dalam rangka pemenuhan hak-hak publik, yaitu hak untuk tahu (right to know), hak untuk diberi informasi (right to be informed), dan hak untuk didengar aspirasinya (right to be heard and to be listened to). Keterbukaan informasi publik memang merupakan hal yang sangat penting dalam penyampaian informasi dari pemerintah kepada masyarakat. Setiap masyarakat memiliki hak untuk mengetahui segala sesuatu tentang pemerintahan. Sesuai dengan Undang-Undang Nomor 14 tahun 2008 menyatakan "menjamin hak warga negara untuk mengetahui rencana pembuatan kebijakan publik, program kebijakan publik, dan proses pengambilan keputusan publik, serta alasan pengambilan suatu keputusan publik; serta mewujudkan penyelenggaraan negara yang baik, yaitu yang transparan, efektif dan efisien, akuntabel serta dapat dipertanggungjawabkan". Kemudahan masyarakat memperoleh informasi secara terbuka tanpa ada hal yang ditutupi oleh pemerintah melalui media yang disediakan sebagai penyedia informasi publik, akan menciptakan karakter masyarakat yang mampu memilih informasi yang valid dan bukan informasi yang tidak benar (Danang: 2019).

Akses pelayanan yang diamanatkan oleh Undang-Undang Keterbukaan Informasi Publik mengarahkan seluruh badan publik yang belanja operasionalnya dibawah anggaran belanja negara/daerah, harus memiliki Pejabat Pengelola Informasi dan Dokumentasi (PPID) yang tugas dan kewajibannya memberikan layanan informasi kepada publik agar terjadi distribusi informasi sehingga aspek yang mengutamakan pelayanan dapat terjadi dengan baik. Sebagai bentuk keharusan untuk setiap lingkungan kementerian dalam negeri dan pemerintahan daerah, melalui Bupati Bungo Pemerintah Daerah Kabupaten Bungo telah membentuk lembaga PPID dengan sistem terpusat (sentralisasi), dimana Dinas Komunikasi, Informatika dan Persandian (KominfoSandi) Kabupaten Bungo sebagai leading Sectornya atau disebut PPID Utama. PPID utama Kabupaten pada dasarnya memiliki tugas yang sama dengan PPID secara umum yaitu menyediakan akses informasi publik bagi pemohon informasi yaitu masyarakat. Dalam menjalankan tugas tersebut, PPID Utama dibantu oleh PPID Pembantu yang merupakan pejabat pada OPD yang membawahi Tata Usaha di Lingkungan Pemerintah Kabupaten Bungo.

Untuk mewujudkan implementasi Undang-Undang Keterbukaan Informasi Publik secara efektif dan efisien, PPID Kabupaten Bungo sebagai pemberi layanan informasi publik kepada masyarakat Kabupaten Bungo, sesuai dengan asas pelayanan informasi publik harus mendorong peran serta masyarakat dalam penyelenggaraan pelayanan informasi publik. Melalui peran aktif PPID bersama dengan pemerintah daerah melakukan upaya pengenalan bentuk akses mendapatkan informasi publik yang tepat, menjadikan ruang yang bagus untuk masyarakat memperoleh haknya dan menghindari medanaptkan informasi palsu serta meningkatkan partisipasi masyarakat kearah demokrasi.

Hak atas informasi oleh masyarakat merupakan hak asasi manusia yang sejatinya harus dipenuhi oleh penyelenggara negara, sesuai dengan amanat UUD RI Tahun 1945 dalam pasal 28F yang mengisyarakat setiap warga negara berhak atas informasi. Informasi yang dikuasi oleh semua Badan Publik tidaklah mutlak milik mereka, akan tetapi dikuasi atas nama rakyat, dan bahwa rakyat harus memiliki akses terhadap informasi tersebut Desi (2008:2). Namun, berdasarkan hasil survey awal peneliti, menemukan sebesar $70 \%$ responden masyarakat Kabupaten Bungo menempatkan argumen bahwasanya belum mengetahui tempat dalam memperoleh informasi publik. Hal ini menunjukkan bentuk pengelolaan melalui pengenalan (sosialisasi) akses mendapatkan informasi publik belum pada hasil yang maksimal. Daftar panjang pekerjaan rumah itu masih berada di depan mata, memperlihatkan belum semua Badan Publik melalui PPID melaksanakan mandat hukum Undang-Undang KIP, masih banyak masyarakat yang belum tahu dan belum memanfaatkan Undang-Undang KIP dalam meminta informasi. Badan publik wajib memberikan informasi kepada masyarakat atau pemohon infrormasi, dengan mekanisme yang ditangani dan dikelola oleh Pejabat Pengelola Informasi dan Dokumentasi (PPID). Kinerja PPID menjadi penting dan faktor penting terselenggaranya keterbukaan Informasi 
Publik yang baik dan memadai. Dengan Demikian tujuan penelitian untuk menganalisis bagaimana kinerja PPID dalam pemenuhan ketersediaan informasi publik.

\section{TINJAUAN PUSTAKA}

\section{Konsep Kinerja}

Kinetika Energi Kerja atau disingkat "kinerja" yang padanannya dalam bahasa Inggris adalah performance, yang sering diindonesiakan menjadi kata performa (Wirawan, 2009). Menurut Pasolong (2014:175) Kinerja pada dasarnya dapat dilihat dari dua segi, yaitu kinerja organisasi dan kinerja pegawai (perindividu). Kinerja organisasi adalah totalitas hasil kerja yang dicapai suatu organisasi Sementara itu kinerja pegawai ialah hasil kinerja perorangan dalam suatu organisasi. Kinerja organisasi dan kinerja pegawai saling berakaitan satu sama lain. Tercapainya keberhasilan dari suatu organisasi tidak lepas dari peranan sumber daya organisasi dalam hal ini pegawai berperan sebagai pelaku untuk mencapai tujuan organisasi itu sendiri.

Widodo M.S (2006:78) juga mengemukakan pandangan tentang kinerja yang diartikan melakukan sesuatu kegiatan dan meyempurnakannya sesuai dengan tanggung jawab dengan hasil seperti yang diharapkan. Kinerja secara umum menurut Schermerhorn, Hunt dan Osborn (2002), kinerja sebagai kualitas dan kuantitas dari pencapaian tugas-tugas, baik yang dilakukan oleh individu, kelompok maupun perusahaan/organisasi

\section{Indikator Kinerja}

Terdapat banyak pengertian apa itu indikator kinerja atau disebut perfomance indicator, ada yang mendefinisikan bahwa: indikator kinerja sebagai ukuran kuantitatif dan kualitatif yang menggambarkan tingkat pencapaian suatu sasaran atau tujuan yang telah ditetapkan oleh organisasi (Moeheriono, 2014:108). Indikator kinerja adalah aspek-aspek yang menjadi ukuran dalam menilai kinerja. Lebih lanjut Mahmudi (2015:153) mendefinisikan indikator kinerja ialah sarana atau alat (means) untuk mengukur hasil suatu aktivitas, kegiatan, atau proses dan bukan hasil atau tujuan itu sendiri (ends).

Menurut Mahsun (2018:31-32) Organisasi sektor publik sifatnya unik, organisasi ini memerlukan ukuran penilaian kinerja yang lebih luas, tidak dilakukan hanya dengan tingkat laba, efisiensi, atau hanya pada ukuran finansial saja. Mahsun membagi 6 (enam) pengukuran kinerja organisasi sektor publik meliputi enam aspek yaitu:

1. Kelompok masukan (input), yaitu segala sesuatu yang dibutuhkan agar pelaksanaan dari setiap kegiatan dapat berjalan untuk menghasilkan keluaran. Kelompok masukan (input) terdiri dari sumber daya manusia, anggaran, sarana/ prasarana, peraturan dan sebagainya.

Sumber daya manusia memiliki posisi sangat strategis dalam organisasi, artinya unsur manusia memegang peranan penting dalam melakukan aktivitas untuk pencapaian tujuan. Untuk itulah maka eksistensi sumber daya manusia dalam organisasi sangat kuat. Untuk mencapai kondisi yang lebih baik maka perlu adanya manajemen terhadap sumber daya manusia secara memadai sehingga terciptalah sumberdaya manusia yang berkualitas, loyal dan berprestasi. Anggaran dapat didefinisikan sebagai pernyataan estimasi kinerja yang hendak dicapai selama periode waktu tertentu yang dinyatakan dalam ukuran finansial. Berdasarkan Kamus Besar Bahasa Indonesia, sarana adalah segala sesuatu yang dipakai dalam bentuk fisik sebagai alat dalam mencapai maksud dan tujuan. Sedangkan prasarana merupakan segala sesuatu yaitu alat tidak langusng yang merupakan penunjang utama terselenggaranya suatu proses.

2. Kelompok proses (process), ialah ukuran dari kegiatan, baik dari segi kecepatan, ketepatan hingga ukuran tingkat akurasi pelaksanaan kegiatan tersebut

3. Kelompok keluaran (output), adalah suatu yang diharapkan langsung dapat dicapai dari suatu kegiatan yang dapat berwujud (tangible), maupun tidak berwujud (intangible)

4. Kelompok hasil (outcome), adalah segala sesuatu yang mencerminkan berfungsinya keluaran kegiatan pada jangka menengah yang mempunyai efek langsung

5. Kelompok manfaat (benefit), adalah sesuatu yang terkait dengan tujuan akhir dari pelaksanaan kegiatan

6. Kelompok dampak (impact), adalah pengaruh yang ditimbulkan baik positif maupun negatif. 
Sedangkan menurut Badan Pengawas Keuangan dan Pembangunan dalam Sinambela (2012:192), terdapat setidaknya 6 (enam) cakupan pengukuran kinerja sektor publik yaitu:

1. Kebijakan, untuk membantu pembuatan maupun pengimplementasian kebijakan tersebut

2. Perencanaan dan penganggaran, untuk membantu perencanaan dan penganggaran atas jasa yang diberikan dan untuk memonitor perubahan terhadap rencana

3. Kualitas, untuk memajukan standarisasi atas jasa yang diberikan maupun keefektifan organisasi

4. Kehematan, untuk meninjau ulang pendistribusian dan keefektifan penggunaan sumber daya

5. Keadilan, untuk meyakini adanya distribusi yang adil dan dilayani semua masyarakat

6. Pertanggungjawaban, untuk meningkatkan pengendalian dan mempengaruhi pembuatan keputusan

Sudarmanto (2009:11) mengutip pada Jhon Miner, mengemukakan adanya empat dimensi yang dapat dijadikan tolak ukur atau indikator dalam menilai kinerja organisasi, yaitu:

1. Kualitas, yaitu : tingkat kesalahan, kerusakan, kecermatan.

2. Kuantitas, yaitu : jumlah pekerjaan yang dihasilkan.

3. Penggunaan waktu dalam bekerja, yaitu : tingkat ketidakhadiran, keterlambatan, waktu kerja efektif/jam kerja hilang.

4. Kerjasama dengan orang/pihak lain dalam bekerja.

Kemudian Agus Dwiyanto (2008:50), ada beberapa indikator yang digunakan untuk mengukur kinerja birokrasi publik, yaitu sebagai berikut :

1. Produktivitas

2. Kualitas Layanan

3. Responsivitas

4. Responsibilitas

5. Akuntabilitas

Sedangkan pengukuran kinerja organisasi yang disampaikan oleh Jerry Harbour (Sudarmanto, 2009:13) merekomendasikan dengan enam aspek, yaitu :

1. Produktivitas : kemampuan dalam menghasilkan barang dan jasa.

2. Kualitas : memproduksi barang dan jasa yang dihasilkan memenuhi strandar kualitas.

3. Ketepatan waktu (timelines) : waktu yang diperlukan dalam menghasilkan produk barang dan jasa tersebut.

4. Putaran waktu : waktu yang dibutuhkan dalam setiap proses perubahan barang dan jasa tersebut, kemudian sampai pada pelanggan/konsumen.

5. Penggunaan sumber daya : sumber daya yang diperlukan dalam menghasilkan produk barang dan jasa tersebut.

6. Biaya : biaya yang diperlukan.

Mahmudi (2015:154) berpendapat indikator kinerja yang baik memiliki sifat memotivasi dan mengarahkan untuk mencapai hasil terbaik. Dalam hal ini fungsi indikator kinerja adalah sebagai alat untuk perbaikan bukan pengendalian.

Dari beberapa indikator kinerja diatas peneliti menggunakan 6 indikator sebagai tolak ukuran dalam menilai kinerja PPID Kabupaten Bungo dalam pemenuhan ketersediaan informasi publik, diantaranya : Produktivitas, Kualitas Layanan, Ketepatan Waktu, Responsivitas, Responsibilitas, dan Kerja Sama.

\section{Tugas dan Wewenang Pejabat Pengelola Informasi dan Dokumentasi}

Berdasarkan Peraturan Bupati Bungo Nomor 8 Tahun 2017 Tentang Standar Operasional dan Prosedur Layanan Informasi pada Pejabat Pengelola Informasi dan Dokumentasi (PPID) di Lingkungan Pemerintah Kabupaten Bungo, tugas dan wewenang PPID Pemerintah Kabupaten Bungo adalah sebagai berikut :

a. Tugas dan Pokok PPID Pemerintah Kabupaten Bungo:

1. Merencanakan, melaksanakan, mengkoordinasikan, mengendalikan pengumpulan informasi, mengklasifikasi informasi, mendokumentasikan informasi dan memberikan pelayanan informasi dari PPID pembantu, di lingkungan Pemerintah Kabupaten Bungo. 
2. Menyimpan, mendokumentasikan, menyediakan dan/atau memberikan pelayanan informasi publik.

3. Melakukan verifikasi bahan informasi publik dari PPID Pembantu sesuai tugas pokok dan fungsi organisasi.

4. Melakukan uji kosekuensi atas informasi publik yang dikecualikan.

5. Melakukan penyediaan pemutakhiran informasi dan dokumentasi agar dapat diakses oleh masyarakat.

6. Melaksanakan advokasi pengaduan dan penyelesaian sangketa informasi publik.

b. Wewenang PPID Pemerintah Kabupaten Bungo:

1. Menolak memberikan informasi yang dikecualikan sesuai dengan ketentuan peraturan perundang-undangan

2. Menentukan atau menetapkan suatu informasi dapat/tidaknya diakses oleh publik

3. Menerima dan memperoleh informasi dari unit kerja komponen/ satuan kerja yang menjadi cakupan kerjanya

4. Mengkoordinasikan pemberian pelayanan informasi dengan PPID pembantu yang menjadi cakupan kerjanya

5. Menungaskan PPID Pembantu untuk membuat, mengumpukan, serta memelihara informasi dan dokumentasi untuk kebutuhan organisasi.

\section{METODE PENELITIAN}

Penelitian ini menggunakan pendekatan metode kualitatif dengan analisis secara deskriptif. Penelitian metode kualitatif dan jenis deskriptif merupakan penelitian yang dimaksudkan untuk mengumpulkan informasi mengenai status fenomena, gejala atau keadaan yang ada, yaitu keadaan gejala menurut apa adanya pada saat penelitian dilaksanakan. Fokus penelitian dalam penelitian ini adalah kinerja Pejabat Pengelola Informasi dan Dokumentasi (PPDI) Kabupaten Bungo dalam pemenuhan ketersediaan informasi publik. Penelitian ini mengambil situs penelitian di Dinas Komunikasi Informatika dan Persandian Kabupaten Bungo. Instrumen penelitiannya adalah peneliti sendiri dengan menggunakan alat bantu penelitian berupa kamera, alat tulis, pedoman wawancara, dan voice recorder. Pemilihan informan dalam penelitian ini menggunakan teknik purposive sampling. Adapun informan dalam penelitian ini yaitu Kepala Bidang Informasi dan Komunikasi Publik, PPID Utama dan PPID Pembantu serta masyarakat Kabupaten Bungo. Teknik pengumpulan data yang digunakan adalah observasi, wawancara dan dokumentasi. Teknik analisis data menggunakan model Miles and Huberman. Selanjutnya penelitian ini menggunakan pengujian validitas data menggunakan Triangulasi Metode, yaitu dengan cara membandingkan informasi atau data dengan cara yang berbeda maka untuk memperoleh kebenaran informasi.

\section{HASIL DAN PEMBAHASAN}

\section{Kinerja Pejabat Pengelola Informasi dan Dokumentasi (PPID) Kabupaten Bungo dalam Pemenuhan Ketersediaan Informasi Publik}

Kinerja merupakan pemaknaan kata yang didefenisikan sebagai suatu hasil kerja yang telah dicapai dalam melaksanakan pekerjaan sesuai tujuan. Menurut Pasolong (2014) kinerja pada dasarnya dapat dilihat dari hasil kerja secara individual atau pegawai dan secara merangkum pencapaian organisasi. Kinerja organisasi dan kinerja pegawai saling berkaitan satu sama lainnya. Tercapainya keberhasilan dari suatu organisasi tidak terlepas daripada peranan pegawai atau sebagai sumber daya manusia organisasi yang berperan sebagai pelaku untuk mencapai tujuan organisasi itu sendiri. Pada penelitian ini berfokus pada melihat bagaimana kinerja daripada Pejabat Pengelola Informasi dan Dokumentasi (PPID) Kabupaten Bungo dalam memenuhi ketersediaan Informasi Publik. Untuk melihat sejauh mana pencapaian hasil kerja PPID tersebut, dalam penelitian ini menggunakan 6 indikator sebagai tolak ukuran, diantaranya : Produktivitas, Kualitas Layanan, Ketepatan Waktu, Responsivitas, Responsibilitas, dan Kerja Sama. 


\section{a. Produktivitas}

Konsep Produktivitas tidak hanya mengukur pada tingkat efisien tetapi juga efektivitas. Menurut Agus (2008) Ukuran produktivitas yang lebih luas yaitu seberapa besar pelayanan publik itu memiliki hasil yang diharapkan sebagai satu indikator kinerja yang penting.

PPID pada lingkungan Pemerintah Daerah Kabupaten Bungo pada capaian kinerja pengelola dan pemberi pelayanan informasi publik belum mencerminkan sesuai sebagaimana tujuan dibentuknya Pejabat Pengelola Informasi dan Dokumentasi (PPID), yaitu dengan maksud mewujudkan pelayanan yang cepat, tepat dan sederhana serta pemberian pelayanan informasi yang dijanjikan mudah pada satu pintu/satu tempat. Baik oleh PPID Utama maupun PPID Pembantu, yang mana korelasi antara keduanya belum menunjukkan hasil yang maksimal.

Berdasarkan hasil penelitian, struktur PPID Utama Kabupaten Bungo berkedudukan pada Dinas Komunikasi, Informatika dan Persandian Kabupatten Bungo. Sedangkan, PPID Pembantu yang merupakan pelaksana sebagai penyedia data/informasi publik sesuai kewenangannya dan bertanggung jawab kepada ketua PPID Utama Kabupaten Bungo, dijabat oleh sekretaris pada OPD-OPD yang ada di Kabupaten Bungo.

Adapun sebagai hasil kerja, PPID Kabupaten Bungo telah melaksanakan tugas merencanakan, melaksanakan, mengkoordinasikan dalam hal pengumpulan data/informasi publik yang didapatkan dari PPID Pembantu pada setiap OPD-OPD yang ada di Kabupaten Bungo, mengklasifikasikan data/infomasi yang didapatkan dan mendokumentasikan data/informasi tersebut baik secara online/digital maupun berkas fisik/non-digital serta telah melakukan pelayanan informasi secara langsung kepada masyarakat. Hal ini sudah sejalan dengan tugas PPID sesuai dengan Peraturan Bupati Bungo Nomor 8 Tahun 2017 tentang SOP Layanan Informasi pada PPID Lingkungan Pemerintah Kabupaten Bungo.

Namun, koordinasi kerja antara PPID Utama dan PPID Pembantu dalam menghasilkan data/informasi publik, diketahui pada hasil yang belum menunjukkan kemaksimalan tugas PPID secara umum. Sesuai tugasnya, harusnya PPID Pembantu membuat suatu daftar data/informasi publik dari satuan unit kerjanya yang ditujukan untuk pelayanan informasi yang nantinya dibutuhkan oleh masyarakat. Dalam hal daftar data/informasi publik tersebut merupakan bentuk tanggung jawab kepada PPID Utama. Berdasarkan hasil wawancara dengan informan, bahwasanya PPID Pembantu masih minim dalam menyerahkan data/informasi publik kepada PPID Utama, bahkan bisa dikatakan sangat sedikit dibandingkan dengan banyaknya jumlah OPDOPD yang ada, dibuktikan berdasarkan data statistik situs web ppid.bungokab.go.id/ (Layanan Informasi Publik Kabupaten Bungo) jumlah dokumen data/informasi publik hanya menunjukkan angka 67, dengan jumlah pemohon informasi berjumlah 9 Pengguna. Hal ini dapat diketahui, PPID Pembantu belum menunjukkan tanggung jawab yang baik terhadap PPID Utama. Jika dibandingkan dengan PPID Pemerintah Provinsi Jambi, menunjukkan angka dokumen sebanyak 6178. Terpaut sangat jauh, yang menitikberatkan belum produktifnya PPID Kabupaten Bungo dalam penyediaan dokumen data/informasi publik.

Harapan agar berjalannya tugas dan fungsi PPID yang sebenarnya adalah mampu menghasilkan produk-produk pelayanan dalam hal ini adalah data/informasi publik baik dokumen dalam bentuk digital maupun non-digital, yang mana pelayanan informasi publik yang dikelola oleh PPID agar mendapatkan hasil kerja yang produktif tentu antara setiap elemen-elemen organisasi terkait saling berkoordinasi. Sejatinya pelayanan berupa pemberiian barang publik, yaitu fokus oleh PPID berupa informasi publik, bukan hanya sebatas mampu melayani masyarakat sesuai asas dan prinsip pelayanan dalam hal ini pelayanan berupa jasa publik, melainkan juga harus mampu memenuhi produk pelayanan itu sendiri yaitu pelayanan barang publik.

\section{b. Kualitas Layanan}

Sumber data utama dari kualitas layanan didapat dari pengguna jasa atau masyarakat dalam melakukan penilaian terhadap kualitas pelayanan. Pelayanan yang baik mampu menciptakan kepuasan bagi penerima pelayanan. Kepuasan akan proses pelayanan hingga kepuasaan menerima hasil dan tujuan dilakukannya pelayanan itu sendiri. Dalam hal pelayanan pemberian 
data/informasi publik oleh PPID Kabupaten Bungo yang terdiri atas pelayanan berupa barang dan jasa, harus mampu mengangkat kepuasan dari penerima pelayanan yaitu masyarakat.

Untuk mencapai kualitas pelayanan yang baik, merujuk pada kepuasan pengguna layanan, pada penelitian ini menggunakan ukuran menurut Zeitham Dkk (1990) dengan dimensi tangible, reability, responsiviness. Assurance, dan empaty. Hasil wawancara bersama dengan beberapa orang masyarakat sebagai penerima pelayanan informasi publik pada PPID Kabupaten Bungo, menyatakan dalam hal pelayanan berupa reability atau kehandalan petugas pelayanan serta sarana fisik penunjang (tangible), menempatkan pujian dan apresiasi yang sangat baik terhadap petugas pelayanan informasi PPID yang mana bertempatkan di Kantor Dinas Kominfo dan Sandi Kabupaten Bungo, bahwasanya dalam memberlakukan masyarakat sebagai penerima pelayanan, petugas memberikan akses sarana prasarana yang mumpuni saat pelayanan berlangsung. Pelayanan dilakukan dengan respon yang cepat sampai pada sikap petugas yang ramah dan sopan pun ditunjukkan. Secara tidak langsung kualitas layanan dari dimensi empaty tercipta sehingga penerima pelayanan merasa sangat terpuaskan.

Kemudian, melihat bagaimana kualitas layanan yang diberikan oleh petugas pemberi data/informasi publik dari dimensi resposiviness atau ketanggapan petugas, tidak pada penilaian yang baik dari sebagian besar penerima layanan informasi publik. Informan masyarakat menyatakan, dalam hal ketanggapan petugas memang telah melakukan pelayanan dengan respon yang cepat, tepat dan cermat. Akan tetapi, pelayanan yang didapati oleh masyarakat, dari respon pelayanan yang tepat waktu tidak secara cepat sesuai waktu pelayanan yang dijanjikan, yang berikbat pada jaminan (assurance) pelayanan tepat waktu tidak ditampakkan dengan baik. Hal ini disebabkan karena data/informasi publik yang dituju belum tersedia. Akibatnya, pelayanan tercipta kurang memuaskan.

\section{c. Ketepatan Waktu}

Menurut Jerry Harbour (Sudarmanto : 2009) ketepatan waktu (timelines) merupakan waktu yang diperlukan dalam menghasilkan barang/jasa. Penyelenggaraan Pelayanan informasi Publik oleh PPID Kabupaten Bungo kepada pemohon informasi dalam hal ini adalah masyarakat, berdasarkan Peraturan Bupati Bungo Nomor 8 Tahun 2017 tentang SOP Layanan Informasi pada PPID Lingkungan Pemerintah Kabupaten Bungo, dilaksanakan pada hari senin-jumat dengan rincian jadwal: senin-kamis Pkl 08.00 s/d 14.00 WIB; Juma'at Pkl 08.00 s/d 11.00 WIB. Dalam hal jangka waktu penyelesaian pemohonan informasi paling lambat 10 hari kerja sejak pemohon melengkapi persyaratan. Ketentuan pemenuhan pemohonan informasi publik tersebut diterapkan apabila pemohon mendatangi langsung Kantor Dinas Kominfo Sandi, artinya permintaan informasi dilakukan secara tatap muka. Lain hal nya apabila pemohon meminta informasi melalui website ppid.bungokab.go.id/ pemohon akan disuguhkan langsung berupa data/informasi publik yang diinginkan tanpa melalui proses administrasi yang panjang.

Pada realisasinya, pemohon yang pernah meminta langsung kepada PPID di Dinas Kominfo Sandi, pernah didapati bahwasanya data/informasi publik yang diminta belum tersedia. Salah satu penyebabnya dikarenakan data/informasi yang dimintai berupa data kewenangan dari salah satu unit kerja OPD yang belum diserahkan. Padahal merujuk pada Peraturan Bupati Bungo Nomor 8 Tahun 2017, diwajibkan setiap OPD yang ada di Kabupaten Bungo membuat dan memperbarui daftar informasi publik dan menyerahkan ke PPID Utama yang ada di Dinas Kominfo Sandi. Secara alur, OPD membuat daftar informasi publik, yang apabila telah tersedia daftar tersebut, akan diserahkan ke PPID Utama secara langsung atau melalui media lainnya. Atas minimnya data/informasi publik dari OPD menyebabkan pelayanan informasi kepada masyarakat menjadi terhambat. Sehingga masyarakat membutuhkan waktu yang lebih lama dalam mendapatkan data/informasi yang diinginkan.

\section{d. Responsibilitas}

Responsibilitas menjelaskan apakah pelaksanaan kegiatan organisasi publik dilakukan sesuai dengan prinsip-prinsip administrasi yang benar atau sesuai dengan kebijakan organisasi (Agus, 2008). Pada dasarnya, sistem kerja struktural PPID Kabupaten Bungo berorientasi pada prinsip-prinsip administrasi. Dalam hal kerjasama antara struktural PPID Utama dan PPID Pembantu sesuai Peraturan Bupati Bungo Nomor 8 Tahun 2017 tentang SOP Layanan Informasi 
pada PPID Lingkungan Pemerintah Kabupaten Bungo, PPID Pembantu berkewajiban menjalankan fungsi pengumpulan informasi, pengklasifikasian informasi serta dokumentasi informasi sesuai kewenangan masing-masing satuan kerja/OPD terkait.

Secara prakteknya, seperti yang disampaikan oleh informan PPID Utama yang ada di Kantor Dinas Kominfosandi Bungo, menyatakan dalam peyerahan kewajiban atas fungsinya, tidak pada semua satuan kerja/OPD-OPD melakukannya. Penempatan bahwa sistem kerja antara PPID Utama dan PPID Pembantu tidak menampakkan secara penuh atas penerapan prinsipprinsip administrasi yang baik. Sebagai pembuktian, disaat pelayanan informasi yang dibutuhkan oleh masyarakat Kabupaten Bungo, ditemukan bahwasanya data/informasi publik yang merupakan data dari kewenangan OPD tertentu yang diinginkan oleh penerima layanan informasi publik belum tersedia. Akibatnya, pelayanan oleh PPID sebagai pemberi layanan informasi publik tidak berjalan semestinya. Hal ini menunjukkan bentuk kerjasama ekternal antara PPID Utama dan PPID Pembantu wilayah kerja Pemerintah Daerah Kabupaten Bungo, belum maksimal dilakukan. Sehingga kinerja dari struktural PPID Kabupaten Bungo belum bisa dikatakan baik.

\section{e. Responsivitas}

Responsivitas adalah kemampuan organisasi dalam mengenali kebutuhan masyarakat untuk menyusun prioritas pelayanan serta pengembangan program-program pelayanan publik sesuai dengan kebutuhan dan aspirasi masyarakat (Agus, 2008).

Berdasarkan temuan diketahui bahwa PPID Utama selaku penyedia informasi baik pelayanan pemberian informasi secara digital maupun non-digital, belum melakukan pengembangan / memperbanyak informasi-informasi yang dibutuhkan masyarakat. Selain pembuktian data/informasi publik secara arsip fisik / non digital yang masih belum banyak dipegang oleh PPID Utama pada Dinas Kominfo dan Sandi Bungo, juga dibuktikan dari jumlah informasi yang tersedia secara digital yaitu pada situs web ppid.bungokab.go.id/ belum ada menunjukkan perubahan update data terbaru. Sebagai contoh, pada saat pandemi Covid-19 ini masyarakat pasti membutuhkan data-data yang berkaitan dengan informasi kasus covid-19 terutama data tentang peningkatan dan penambahan positif covid-19.

\section{f. Kerjasama}

Kejasama dalam suatu organisasi dalam mencapai tujuan organisasi terkait dilakukan bersifat internal dan eksternal, bersifat hampir untuk semua organisasi publik yang mengemban fungsi pelayanan publik untuk khalayak orang banyak. Hubungan antar struktural organisasi maupun dengan antar diluar daripada tugas dan fungsi dari oraganisasi yang memiliki keterkaitan tujuan yang hendak dicapai

Dalam menjalankan tugas dan wewenangnya, sebagai penyedia sekaligus pemberi pelayanan data/informasi publik kepada masyarakat, struktural PPID Kabupaten Bungo harus saling bekerjasama agar pelaksanaan pelayanan berjalan sesuai alur pelayanan oleh PPID. Dalam hal kerjasama antar PPID bersifat kerjasama internal dan eksternal. PPID Utama bertanggung jawab kepada atasan PPID Kabupaten Bungo, dalam hal ini adalah Bupati Bungo. Adapaun kerjasama lingkup internal dilakukan antar tim struktural PPID Utama yang terdiri atas kerja sama oleh jabatan sebagai Ketua PPID Utama, jabatan sebagai Sekretaris PPID Utama, jabatan Sekretariat PPID Utama yang terdiri dari Pranata: humas, komputer, arsiparis yang dirangkap oleh satu orang sebagai Operator PPID Utama, dan jabatan sebagai Penyelesaian Sangketa pelayanan informasi publik, yang mana saat ini sruktural PPID Utama berkedudukan di Dinas Komunikasi, Informatika, dan Persandian Kabupaten Bungo (Dinas Kominfosandi Bungo). PPID Utama sebagai penyelenggara pemberian layanan informasi publik di lingkungan Pemerintah Daerah Kabupaten Bungo secara tatap muka menyediakan pelayanan pemberian informasi kepada masyarakat yang datang langsung ke Kantor Dinas Kominfosandi Kabupaten Bungo, apabila masyarakat tidak menemukan data/informasi publik secara digital pada situs web PPID Kabupaten Bungo.

Sebagai bahan informasi diluar kuasa kewenangannya yang akan diberikan kepada penerima informasi publik, bentuk kerjasama eksternal PPID, PPID Utama dibantu oleh PPID Pembantu yang setiap pejabatnya berkedudukan di setiap OPD-OPD yang ada di Kabupaten Bungo yang merupakan pejabat sebagai Sekretaris Badan Publik yang bersangkutan, serta 
bekerjasama dengan Sekreariat Daerah Kabupaten Bungo sebagai tim pertimbangan PPID Kabupaten Bungo.

Sesuai dengan fungsinya, PPID pembantu bertanggung jawab kepada Ketua PPID Utama dalam pengumpulan informasi, pengklasifikasian informasi serta dokumentasi informasi sesuai kewenangan masing-masing satuan kerja terkait. Sedangkan Tim Pertimbangan Setda Bungo bekerjasama dengan pihak PPID Utama dalam hal penyelesaian sangketa informasi publik, dalam artian pada saat masyarakat meminta informasi yang dikecualikan oleh OPD, namun disisi lain masyarakat bersikeras untuk tetap memperoleh informasi tersebut.

\section{KESIMPULAN}

1. PPID Kabupaten Bungo sebagai pengelola dan pemberi pelayanan informasi publik belum mencerminkan sesuai sebagaimana tujuan dibentuknya Pejabat Pengelola Informasi dan Dokumentasi (PPID), yaitu dengan maksud mewujudkan pelayanan yang cepat, tepat dan sederhana serta pemberian pelayanan informasi yang dijanjikan mudah pada satu pintu/satu tempat Secara realisasinya, pelaksanaan pelayanann informasi publik kepada masyarakat masih banyak didapati permintaan informasi yang belum ada dikarenakan informasi publik yang tersedia belum lengkap.

2. PPID Pemberi pelayanan informasi publik secara langsung pada Kantor Dinas Komunikasi, Informatika dan Persandian Kabupaten Bungo secara kualitas layanan jaminan (assurance) tepat waktu belum ditampakkan dengan baik. Hal ini disebabkan karena data/informasi publik yang dituju belum tersedia. Akibatnya, pelayanan tercipta kurang memuaskan.

3. Minimnya data/informasi publik yang tersedia menempatkan bahwa sistem kerja serta kerjasama antara PPID Utama dan PPID Pembantu pada PPID Kabupaten Bungo belum menampakkan secara penuh atas penerapan prinsip-prinsip administrasi serta tugas, fungsi dan wewenang masing-masing.

4. Belum adanya pengembangan yang signifikan dalamm melakukan perbanyakan informasiinformasi publik yang disediakan nantinya kepada calon penerima pelayanan informasi publik baik secara digital melalui web resmi Sistem Informasi Publik PPID Kab. Bungo maupun secara non-digital yang tersedia di Kantor Dinas Komunikasi, Informatika dan Persandian Kabupaten Bungo.

\section{DAFTAR PUSTAKA}

Dwiyanto, Agus. 2008. Reformasi Birokrasi Publik di Indonesia. Yogyakarta : PPSK-UGM

Jr, Jhon R. Schermerhorn dkk. 2020. Organizational Behavior (cetakan ke tujuh). United States of America : Jhon Willey.

M.S., Joko Widodo. 2006. Membangun Birokrasi Berbasis Kinerja. Jakarta : Bayumedia Publishing.

Mahmudi. 2015. Manajemen Kinerja Sektor Publik (edisi kedua). Yogyakarta : UPP STIM YKPN.

Mahsun, Mohamad. 2018. Pengukuran Kinerja Sektor Publik (edisi pertama, cetakan ketujuh). Yogyakarta : BPFE Yogyakarta.

Mardiasmo. 2004 Otonomi dan Manajemen Keuangan Daerah. Yogyakarta : Andy.

Moeheriono. 2014. Pengukuran Kinerja Berbasis Kompetensi (cetakan kedua). Jakarta : Rajagrafindo Persada.

Pasolong, Harbani. 2014. Teori Administrasi Publik. Bandung : Alfabeta.

Prayitno, Dessy Eko dkk. 2008. Modul bagi Badan Publik melaksanakan Undang-Undang Nomor 14 Tahun 2008. Jakarta : Indonesian Center for Environmental Law

Sastro, Dhoho A. 2010. Mengenal Undang-Undang Keterbukaan Informasi Publik, Penerbit Lembaga Bantuan Hukum Masyarakat. Jakarta.

Sinambela, Lijan P. 2012. Kinerja Pegawai: Teori Pengukuran dan Implikasi. Yogyakarta : Graha Ilmu. 
Sirajuddin dkk. 2011. Hukum Pelayanan Publik : Berbasis Partisipasi \& Keterbukaan Informasi. Malang : Setara Press.

Sudarmanto. 2009. Kinerja dan Pengembangan Kompetensi SDM. Yogyakarta : Pustaka Pelajar.

Trijayanto, Danang \& Iqbal Aidar Idrus. 2019. Peran Ppid Pemerintah Kota Yogyakarta dalam Pengelolaan dan Penyelengaraan Keterbukaan Informasi Publik. Jurnal IKRAITHHUMANIORA. Volume 3 Nomor 1.

Wirawan. 2009. Evaluasi Kinerja Sumber Daya Manusia Teori, Aplikasi dan Penelitian. Jakarta : Salemba Empat.

\section{Undang-Undang dan Peraturan}

Undang-Undang Dasar Republik Indonesia Tahun 1945

Undang-Undang Nomor 14 Tahun 2008 tentang Keterbukaan Informasi Publik

Peraturan Menteri Dalam Negeri Nomor 35 Tahun 2010 tentang Pedoman Pengelolaan Pelayanan Informasi dan Dokumentasi di Lingkungan Kementrian Dalam Negeri dan Pemerintahan Daerah.

Peraturan Bupati Bungo Nomor 8 Tahun 2017 tentang Standar Operasional dan Prosedur Layanan Informasi pada Pejabat Pengelola Informasi dan Dokumentasi (PPID) di Lingkungan Pemerintah Kabupaten Bungo.

\section{Website}

https://ppid.bungokab.go.id/ 